\title{
Evaluasi Parameter Akustik Objektif Gereja X di Surabaya
}

\author{
Gontjang Prajitno, ${ }^{*}$ Regina Ratu, Susilo Indrawati, dan Suyatno \\ Departemen Fisika-FIA, Institut Teknologi Sepuluh Nopember (ITS) \\ Kampus ITS Sukolilo, Surabaya 60111
}

\begin{abstract}
Intisari
Gereja merupakan salah satu bangunan yang memiliki citra yang khusyuk dan hikmat, sehingga perbedaan dari tekanan bunyi, keras lembutnya suara dan perjalanan bunyi yang akan menentukan kualitas dan kuantitas bunyi yang dihasilkan berdampak kenyamanan setiap jemaat dan tujuan setiap acara yang dilaksanakan. Dalam upaya untuk memenuhi standar sebuah ruang ibadah gereja maka peneilitian ini bertujuan untuk mengetahui distribusi nilai parameter yang berada pada jemaat. Parameter yang dievaluasi meliputi persebaran tingkat tekanan bunyi, persebaran waktu dengung, persebaran tingkat kejelasan suara $\mathrm{D}_{50}$ (definition) dan $\mathrm{C}_{80}$ (clarity) suara musik. Dalam penelitian ini, pengujian dilakukan di ruang ibadah gereja X di Surabaya. Dari hasil pengukuran dan analisa didapat bahwa memiliki nilai kriteria kebisingan pada ruang ibadah gereja $\mathrm{X}$ bernilai NC 40 s.d NC 45. Nilai ini masih berada diatas nilai tingkat kebisingan yang direkomendasikan untuk fungsi ruang ibadah gereja Parameter waktu dengung berkisar antara 0,42-0,568 detik. Nilai $\mathrm{C}_{80}$ berkisar antara 2,94 dB hingga 12,38 dB. Maka secara keseluruhan nilai waktu dengung belum memenuhi standar dan untuk nilai $\mathrm{C}_{80}$ masih belum memenuhi standar. Sedangkan, untuk nilai $\mathrm{D}_{50}$ yang menyatakan kejelasan suara vokal bernilai antara $36,82 \%$ hingga $86,96 \%$ sudah memenuhi standart dibeberapa titik, untuk ruang dengan fungsi pidato.
\end{abstract}

\begin{abstract}
The church is one of the buildings that has a solemn image and wisdom, so the difference from the sound pressure, the loudness of the sound and the sound journey that will determine the quality and quantity of the resulting sound impact the comfort of each congregation and the purpose of each event.In an effort to meet the standards of a church worship space, this research is aimed at knowing the distribution of parameter values residing in the congregation. The parameters evaluated include the spreading of the sound pressure level, the dispersion of the humming time, the distribution of the sound clarity of $\mathrm{D}_{50}$ (definition) and the $\mathrm{C}_{80}$ (clarity) of the musical sound.In this research, the testing was done in the X church worship room in Surabaya.From the measurement and analysis it is found that the value of noise criteria in the $\mathrm{X}$ church worship room is NC 40 s.d NC 45. This value is still above the recommended noise level for the function of the church worship room. The humming time parameter ranges from 0.42 to 0.568 seconds. The $\mathrm{C}_{80}$ value ranges from $2.94 \mathrm{~dB}$ to 12.38 $\mathrm{dB}$.So overall the value of the humming time has not met the standard and for the value of $\mathrm{C}_{80}$ still not meet the standard.Meanwhile, for the value of $\mathrm{D}_{50}$ which states the clarity of vowel sounds worth between $36.82 \%$ to $86.96 \%$ has met the standard at some point, for space with speech function.
\end{abstract}

KATA KUNCI: Bising latar belakang, waktu dengung, Definition, Clarity

http://dx.doi.org/10.12962/j24604682.v14i2.3687

\section{PENDAHULUAN}

Akustik merupakan ilmu rekayasa bunyi yang mempelajari perilaku bunyi, untuk perilaku bunyi dalam ruang lebih dikenal dengan akustik ruang. Akustik ruang adalah salah satu aspek penting yang memperhatikan kualitas suara dalam suatu ruang, melalui penilaian-penilaian yang dilakukan secara objektif. Penilaian objektif dilakukan dengan parameterparameter akustik menggunakan alat ukur yang sesuai dengan kaidah yang sudah ditentukan. Parameter tersebut diantaranya adalah tingkat tekanan bunyi, kriteria kebisingan (noise criteria-NC), waktu dengung, kejelasan suara baik suara ucap

*E-MAIL: gont jang@physics.its.ac.id
(Definition $/ D_{50}$ ) dan kejelasan suara instrumen $\left(\right.$ Clarity/ $\left.C_{80}\right)$. Gereja merupakan bangunan yang dirancang memiliki citra keagungan Tuhan, sehingga kegiatan ibadah yang khusyuk dan hikmat menjadi aspek utama. Dalam bangunan gereja suasana tersebut dapat terbentuk dengan desian akustik yang tepat. Seperti yang kita ketahui bahwa ada dua aktivitas dalam ruang ibadah gereja, yang digunakan untuk khotbah dan musik. Tentunya ada perbedaan dari tekanan bunyi, keras lembutnya suara dan perjalanan bunyi yang akan menentukan kualitas dan kuantitas bunyi yang dihasilkan [1, 2].

Akustik pada ruang sering dibagi menjadi akustik ruang yang yang menangani bunyi yang dikehendaki dan kontrol kebisingan yang menangani bunyi yang tak dikehendaki. Akustik ruang dilakukan untuk mengetahui kualitas ruangan tersebut. Pada penelitian ini dilakukan evaluasi parameter akustik secara objektif pada ruang ibadah yang berdasarkan pada parameter objektif yaitu nilai kriteria kebisingan, dis- 


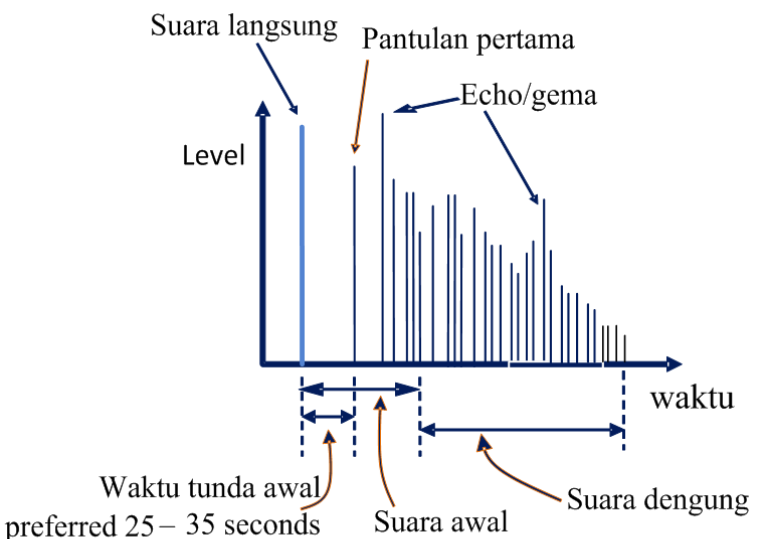

Gambar 1: Respons impuls sebuah ruang [5].

tribusi tingkat tekanan bunyi, waktu dengung dan kejelasan suara vokal maupun instrumen.

Bunyi adalah bentuk gelombang longitudinal yang dalam perambatannya membutuhkan medium untuk kemudian sampai pada pendengar. Bunyi bisa berasal dari dalam ruangan maupun luar ruangan. Bunyi yang berasal bukan dari sumber bunyi utama disebut juga dengan bising latar belakang. Bising latar belakang ini lebih bersifat mengganggu dan selalu berbunyi secara kontinyu. Bising latar belakang tidak dapat sepenuhnya dihilangkan akan tetapi dapat dikurangi melalui serangkaian perlakuan akustik terhadap ruangan. Untuk mengevaluasi kebisingan pada ruangan maka digunakan besaran kriteria kebisingan [3]. Menurut Boris (2010) standar kriteria kebisingan ruang ibadah gereja yaitu NC 25-30 jika ruang ibadah gereja memiliki nilai NC diatas nilai tersebut maka dapat dikatakan bahwa ruang tersebut bising dan akan mempengaruhi tingkat kejelasan bunyi yang akan didengarkan oleh audiens [4].

Sumber dasar informasi mengenai bunyi yang dapat didengar didalam ruang disebut respons impuls. Gambar 1 menunjukkan ilustrasi dari energi pada respons impuls sebuah ruang.

Berdasarkan pada energi pada respon impulse seperti pada Gambar 1, secara objektif dapat hitung beberapa parameter akustik seperti waktu dengung, dan kejelasan suara. Waktu yang diperlukan bunyi yang berada di suatu ruangan untuk meluruh sebanyak $60 \mathrm{~dB}$ setelah sumber suara berhenti seketika disebut waktu dengung (reverberation time-RT) [5]. Waktu dengung menunjukkan seberapa lama energi suara dapat bertahan dalam ruangan, seringkali parameter ini menjadi acuan awal dalam mendesain suatu ruangan sesuai dengan fungsi ruangan tersebut. Waktu dengung sangat menentukan dalam pengukuran tingkat kejelasan suara vokal maupun instrument. Suatu ruang yang memiliki waktu dengung yang terlalu panjang akan menyebabkan penurunan tingkat kejelasan suara yang didengarkan oleh audiens, karena suara langsung masih dipengaruhi oleh suara pantul. Parameter untuk mengukur tingkat kejelasan bunyi pada suara yaitu tingkat

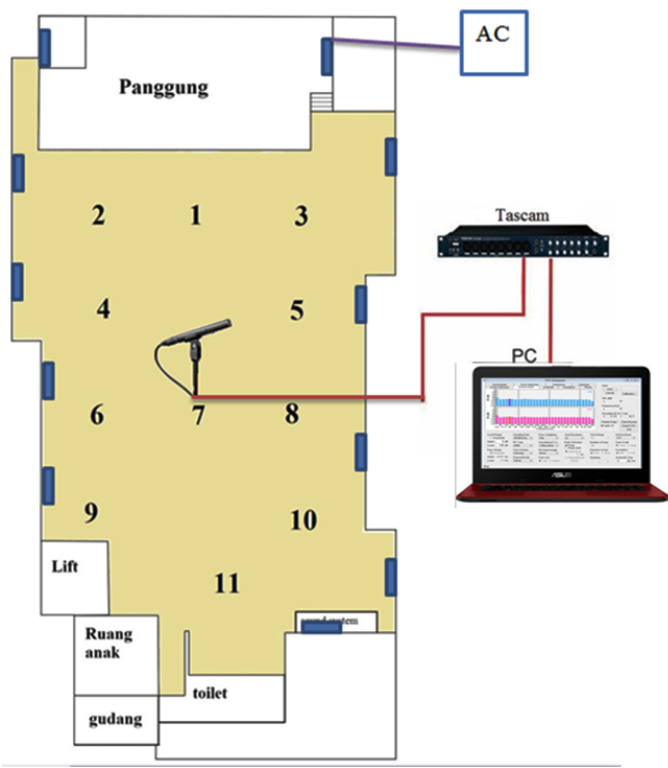

Gambar 2: Skema alat untuk pengukuran kriteria kebisingan.

kejelasan suara vokal $\left(\mathrm{D}_{50}\right)$ yang menyatakan suatu tingkat kejelasan suara saat suatu bangunan yang difungsikan untuk pidato dan tingkat kejernihan suara instrument $\left(\mathrm{C}_{80}\right)$ untuk mendengar bunyi secara jelas, bersih dan detail-detailnya dapat mudah dibedakan [6-8].

Penelitian ini melakukan evaluasi terhadap parameter akustik ruang dari ruang ibadah gereja X di Surabaya. Adapun parameter yang diteliti dalam penelitian ini adalah parameter akustik secara objektif. Untuk mengetahui nilai parameter akustik yang meliputi kriteria kebisingan, distribusi tingkat tekanan bunyi, kejelasan suara vokal dan $\mathrm{C}_{80}$ (clarity) tingkat kejernihan suara instrument.

\section{METODOLOGI}

Seperti yang telah disampaikan pada bagian I evaluasi dilakukan terhadap parameter kriteria kebisingan, distribusi tingkat tekanan bunyi, $\mathrm{D}_{50}$, dan $\mathrm{C}_{80}$. Dalam melakukan evaluasi terhadap parameter akustik, dilakukan melalui metode, yaitu dengan menggunakan suara white noise dan respons impuls.

\section{Pengukuran kriteria kebisingan}

Pengukuran kriteria kebisingan dilakukan menggunakan dua metode. Metode yang pertama dilakukan saat peralatan mekanikal-mekanikal dalam ruang seperti AC, peralatan sound system dimatikan. Tujuannya adalah untuk mengetahui pengaruh bising latar belakang yang dihasilkan dari luar ruangan. Metode yang kedua agar sesuai dengan kondisi ruangan yang biasa digunakan (seperti $\mathrm{AC}$, peralatan sound system) dinyalakan, tujuannya adalah untuk mengetahui pengaruh bising latar belakang yang dihasilkan dari dalam ruangan tersebut. Skema alat untuk pengukuran kriteria kebisingan ditunjukkan Gambar 2. 


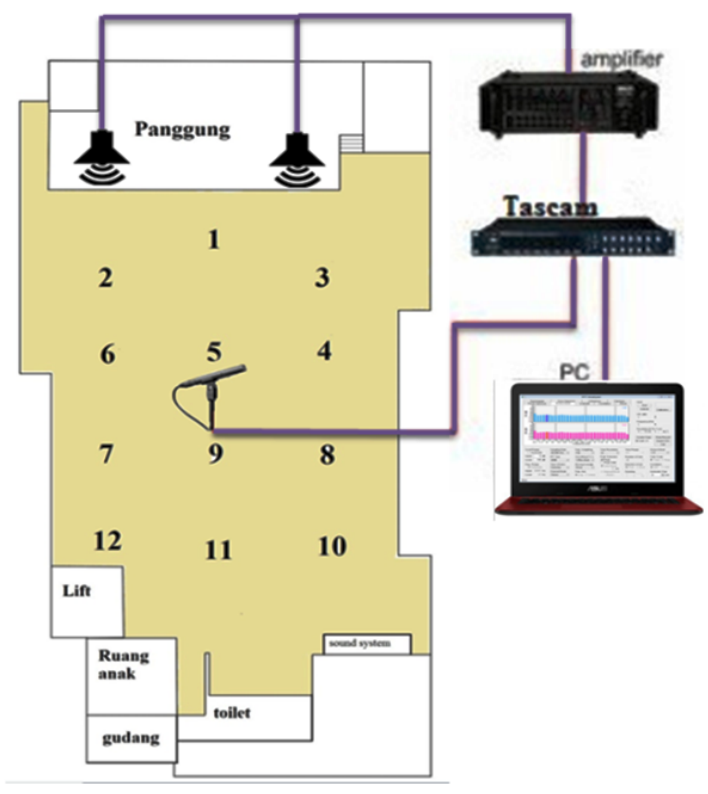

Gambar 3: Skema alat untuk pengukuran sebaran SPL.

\section{Pengukuran distribusi parameter akustik ruang}

Pengukuran distribusi parameter akustik ruang dilakukan dengan mengukur distribusi tingkat tekanan bunyi (SPL). Pengukuran ini bertujuan untuk mengetahui persebaran energi sumber suara dalam ruang ibadah gereja. Pengukuran ini dilakukan dengan menggunakan suara berupa white noise dengan menggunakan perangkat lunak YMEC yang berasal dari speaker yang terpasang. Sementara untuk parameter waktu dengung, clarity dan definition, pengukuran menggunakan sumber respon impuls yang didasarkan pada ISO 3882-1. Sementara sumber suara yang digunakan berasal dari pengeras suara ruang ibadah gereja tersebut. Gambar 3 menunjukkan posisi titik ukur dalam pengukuran.

\section{HASIL DAN PEMBAHASAN}

\section{Hasil pengukuran kriteria kebisingan}

Pengukuran kriteria kebisingan dilakukan untuk mengetahui bising latar belakang dari ruangan. pengukuran dilakukan ketika kondisi riil yaitu ketika peralatan mekanikal dalam kondisi hidup (seperti AC, lampu, dan alat-alat sound system). berdasarkan nilai bising latar belakang, kemudian dapat dibuat mejadi satu nilai yang menggambarkan kelas atau kriterian bising yang ada atau disebut NC (Noise Criteria). Gambar 5 menunjukkan besarnya NC dari ruang yang diukur.

Pada Gambar 5 menunjukkan bahwa nilai NC ketika AC dinyalakan adalah sebesar 40 s.d 45, sedangkan nilai NC yang diperbolehkan sebesar 25 s.d 30. Ini berarti nilai NC yang didapatkan ketika pengukuran lebih tinggi dibandingkan dengan nilai yang direkomendasikan. Sementara Gambar 4 menunjukkan sebaran dari nilai NC ruang.

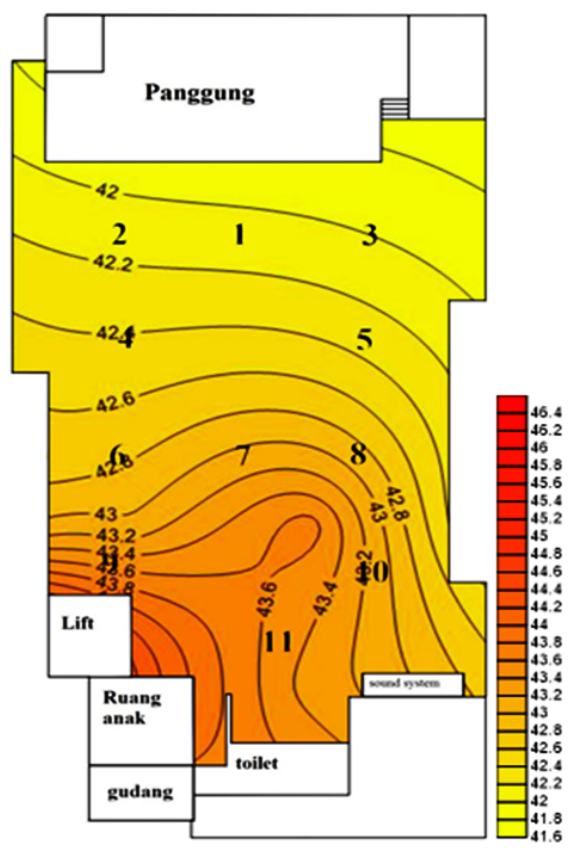

Gambar 4: Pesebaran nilai NC di ruang ibadah Gereja X.

Sesuai dengan Gambar 4, nilai NC paling tinggi berada dibagian belakang yaitu 45. Pada posisi ini berhubungan dengan lift sebagai sumber bising. Sementara pada bagian yang lain relatif rendah yaitu sekitar 42 . Sumber bising pada bagian ini adalah pendingin ruang serta komponen pengeras suara yang terpasang.

\section{Distribusi tingkat tekanan bunyi}

Salah satu cara untuk mengetahui kriteria suatu ruangan adalah baik dengan melihat distribusi tingkat tekanan bunyi yang ada dalam ruangan. Perbedaan tingkat tekanan bunyi antara titik terjauh dan titik terdekat dari panggung (sumber suara) tidak lebih besar dari $3 \mathrm{~dB}$. Pengukuran distribusi SPL dilakukan dengan menggunakan sumber suara berupa white noise, dengan sumber berupa pengeras suara yang terpasang di ruang dan ruang dalam keadaan kosong (unoccupied). Berdasarkan hasil pengukuran yang telah dilakukan, maka diperoleh nilai distribusi SPL seperti pada Gambar 6.

Berdasarkan pada Gambar 6, nilai SPL pada titik ukur 1 yang berada paling dekat memiliki SPL sebesar 89,73 dBA di frekuensi overall (all-freq), sementara untuk titik terjauh (titik 10, 11 dan 12) sebesar $91 \mathrm{dBA}$. Hal ini menunjukkan bahwa distribusi parameter SPL atau energi dalam ruang cukup merata.

\section{Respon impuls}

Pengukuran respon ruangan didapatkan dengan membandingkan sinyal impuls yang telah berinteraksi dengan ruangan terhadap sinyal impuls masukan (konsep fungsi transfer), melalui pengukuran respon impuls dapat diperoleh parameter akustik seperti RT, $\mathrm{C}_{80}$ dan $\mathrm{D}_{50}$. Pengukuran respon impuls dilakukan dengan memerikan suara impuls yang berasal dari 


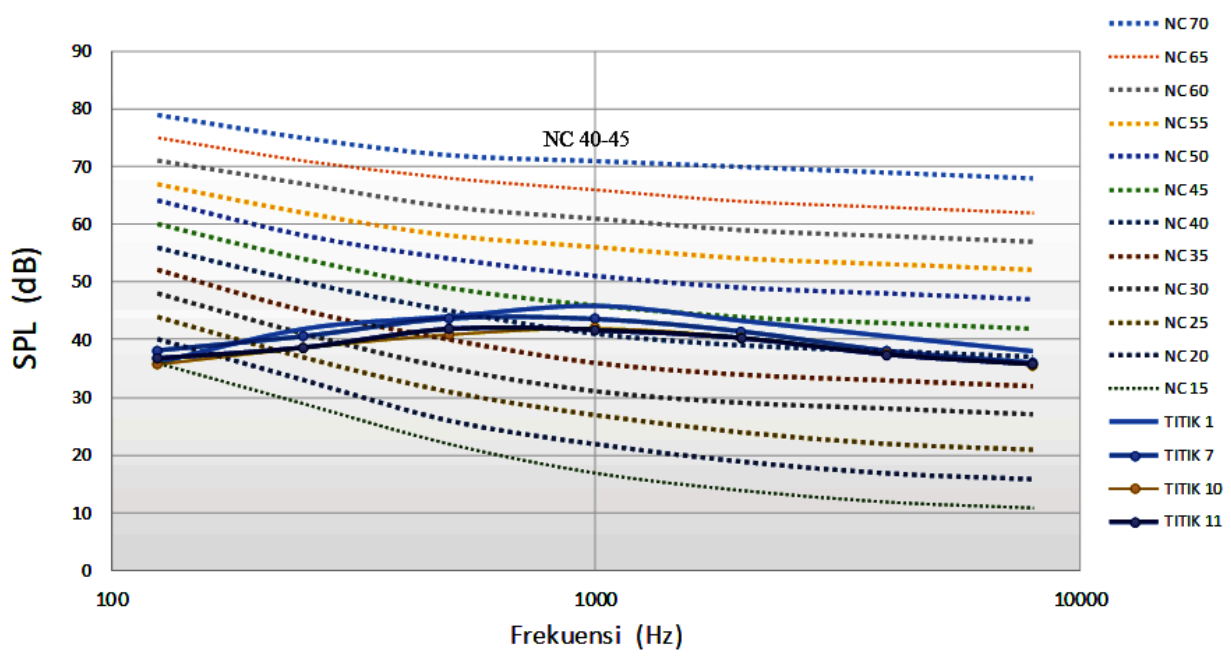

Gambar 5: Grafik NC saat semua peralatan mekanikal dalam keadaan hidup.

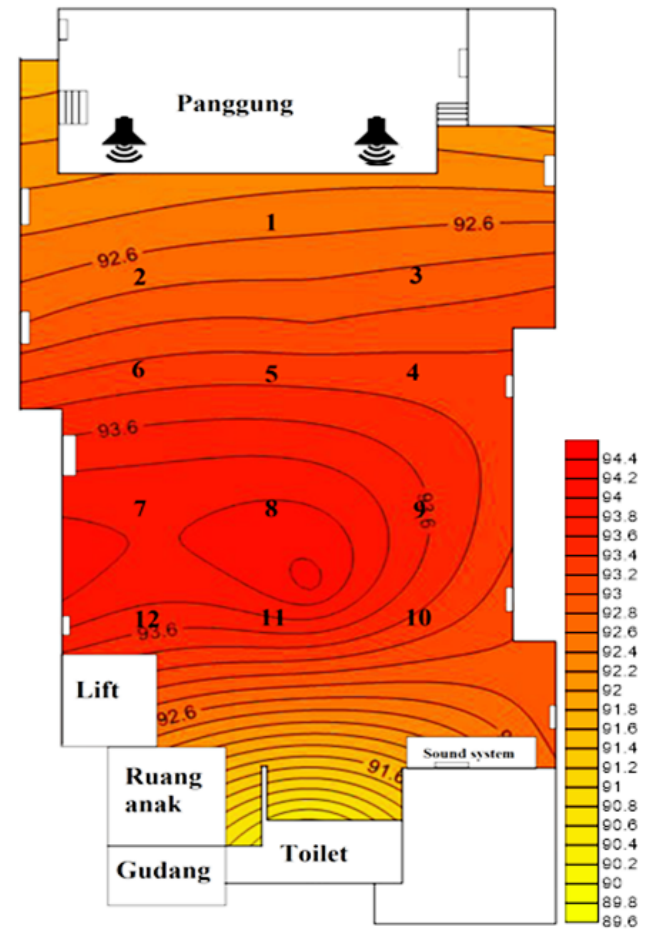

Gambar 6: Persebaran SPL pada ruang ibadah.

sumber suara impuls melalui pengeras suara yang terpasang. Tabel I menunjukkan nilai parameter yang diperoleh melalui analisa suara pada ruang pada frekuensi $1000 \mathrm{~Hz}$.

Dari hasil pengukuran seperti pada Tabel I, maka dapat dilakukan pemetaan distribusi parameter RT, sehingga dapat diketahui lebih jelas persebaran waktu dengung dalam ruang ibadah tersebut. Sementara jika kita bandingkan dengan parameter RT yang disyaratkan untuk ruang ibadah tampak seperti pada Gambar 7.
TABEL I: Hasil pengukuran Respon impuls pada Frekuensi $1000 \mathrm{~Hz}$.

\begin{tabular}{cccc}
\hline Titik & \multicolumn{3}{c}{ P a r a m e t e r } \\
& RT (s) & $C_{80}(\mathrm{~dB})$ & $\mathrm{D}_{50}(\%)$ \\
\hline & & & \\
1 & 0,513 & 2,94 & 36,82 \\
2 & 0,524 & 3,59 & 49,11 \\
3 & 0,501 & 6,05 & 49,71 \\
4 & 0,506 & 6,66 & 56,40 \\
5 & 0,438 & 10,73 & 67,82 \\
6 & 0,42 & 7,45 & 52,52 \\
7 & 0,451 & 6,15 & 56,44 \\
8 & 0,474 & 10,73 & 67,25 \\
9 & 0,454 & 11,47 & 72,11 \\
10 & 0,512 & 10,49 & 82,40 \\
11 & 0,568 & 12,38 & 86,96 \\
12 & 0,499 & 9,91 & 70,43 \\
\hline \hline
\end{tabular}

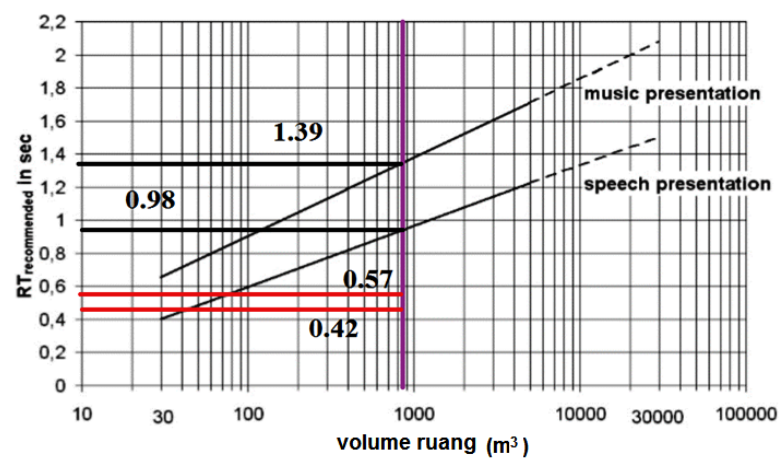

Gambar 7: Waktu dengung hasil pengukuran berdasarkan volume ruang.

Dari Gambar 7, dapat diketahui bahwa waktu dengung pada ruang ibadah gereja $X$ yang bervolume $867,38 \mathrm{~m}^{3}$ berkisar antara 0,99-1,39 detik. Berdasarkan hasil pengukuran waktu dengung seperti terlihat pada Tabel I bernilai 0,42-0,568 


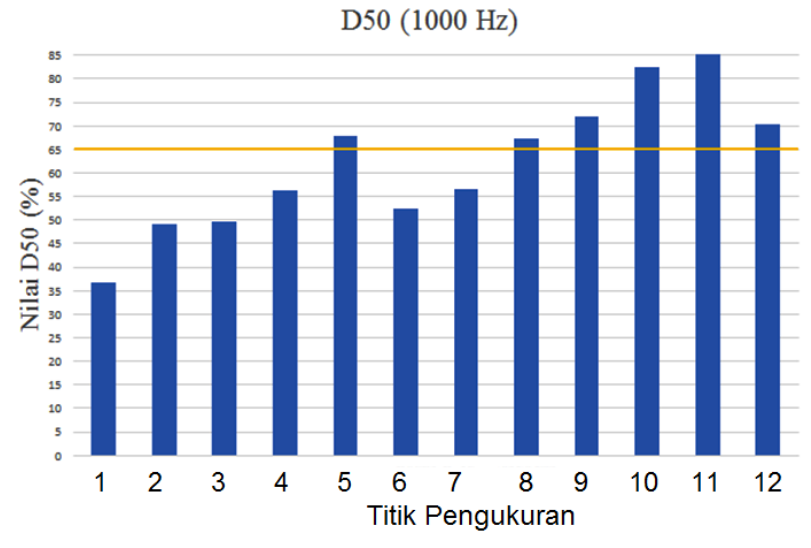

Gambar 8: Grafik perbandingan $\mathrm{D}_{50}$ pada ruang ibadah terhadap nilai rekomendasi.

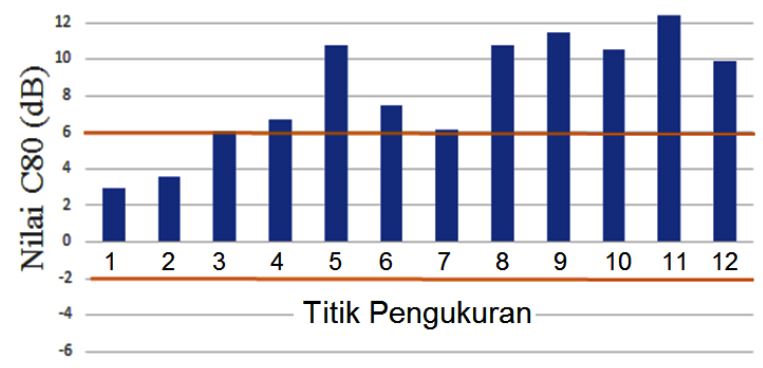

Gambar 9: Grafik nilai $\mathrm{C}_{80}$ yang memenuhi standar yang direkomendasikan untuk $1000 \mathrm{~Hz}$.

detik. Nilai ini masih terlalu rendah untuk kejelasan suara instrument dan rendah untuk kejelasan suara vokal. Bila dilihat dari tingkat waktu dengung untuk khotbah (speech) dan musik memiliki kesenjangan dimana waktu dengung untuk khotbah adalah 0,5 -1,4 detik sedangkan untuk musik adalah 1,4-2,6 detik, maka ruang ibadah gereja $\mathrm{X}$ dengan rentang waktu dengung seperti pada Tabel I lebih sesuai dengan waktu dengung untuk mendengarkan khotbah.

Saat ruang ibadah gereja digunakan untuk mendengarkan khotbah maka parameter $\mathrm{D}_{50}$ atau kejelasan dalam mendengarkan suara vokal yang merata dalam suatu ruangan menjadi tuntutan. $\mathrm{D}_{50}$ merupakan rasio antara energi yang diterima pada $50 \mathrm{~ms}$ pertama dengan total energi yang diterima. Berdasarkan pada Tabel I maka diperoleh nilai $\mathrm{D}_{50}$ pada ruang ibadah gereja $\mathrm{X}$ disetiap titik pengukuran berada pada rentang nilai $36,82-86,96 \%$ di frekuensi $1000 \mathrm{~Hz}$. Menurut Ribeiro nilai optimum $\mathrm{D}_{50}$ yang direkomendasikan untuk ruang konferensi sebesar $65 \%$.

Berdasarkan Gambar 8 yang menunjukkan bahwa nilai tingkat kejelasan suara vokal pada setiap titik pengamatan ada yang sesuai dengan nilai yang direkomendasikan. Seperti pada titik 5, titik 8, titik 9, titik 10, titik 11 dan titik 12 . Sehingga dari hasil yang didapatkan diketahui bahwa tingkat kejelasan suara vokal pada ruang ibadah gereja Xsudah baik dibeberapa titik dalam artian audiens dapat menerima informasi dengan jelas.

Tingkat kejelasan suara musik (instrumen) yang ditunjukkan dari nilai $\mathrm{C}_{80}$ menjadi hal yang dapat menambah kekhusyukan. Nilai $\mathrm{C}_{80}$ diperoleh dengan membandingkan jumlah energi suara yang datang pada selang waktu pada 0-80 ms awal terhadap jumlah energi suara yang datang setelahnya hingga suara tersebut menghilang. Menurut hasil pengukuran nilai disemua titik pengukuran berada direntang 2,94-12,38 dB. Sedangkan menurut Renkus Heinz nilai $\mathrm{C}_{80}$ yang direkomendasikan berada diantara $-2 \mathrm{~dB}$ s.d $6 \mathrm{~dB}$. Gambar 9 menunjukkan gambar hubungan $\mathrm{C}_{80}$ pada tiap titik pengukuran yang direkomendasikan.

Dapat dilihat pada Gambar 9 bahwa pada beberapa titik nilai $\mathrm{C}_{80}$ telah memenuhi standar rekomendasi dari nilai $\mathrm{C}_{80}$ sebuah ruang ibadah gereja yang menggunakan alat musik. Seperti pada Tabel I yang menunjukkan bahwa beberapa titik pengamatan belum memenuhi nilai standar rekomendasi pada frekuensi $1000 \mathrm{~Hz}$. Sehingga dapat disimpulkan bahwa nilai $\mathrm{C}_{80}$ dalam ruang ibadah gereja $\mathrm{X}$ belum memenuhi kriteria ruang sebagai fungsi ruang musik, khususnya untuk musik yang menggunakan elektronik.

\section{SIMPULAN}

Berdasarkan hasil penelitian yang telah dilakukan untuk mengevaluasi parameter akustik objektif ruang ibadah gereja $\mathrm{X}$ di Surabaya, maka dapat ditarik simpulan sebagai berikut:

1. Hasil nilai kriteria kebisingan pada ruang ibadah gereja X bernilai NC 40 s.d NC 45. Nilai ini masih berada di atas nilai tingkat kebisingan yang direkomendasikan untuk fungsi ruang ibadah gereja.

2. Nilai parameter waktu dengung berkisar antara 0,420,568 detik. Nilai $\mathrm{C}_{80}$ berkisar antara 2,94 dB hingga $12,38 \mathrm{~dB}$. Maka secara keseluruhan nilai waktu dengung belum memenuhi standar dan untuk nilai $\mathrm{C}_{80}$ masih belum memenuhi standar. Sedangkan, untuk nilai $\mathrm{D}_{50}$ yang menyatakan kejelasan suara vokal bernilai antara $36,82 \%$ hingga $86,96 \%$ sudah memenuhi standar dibeberapa titik, untuk ruang dengan fungsi pidato.
[1] Y.B. Mangunwijaya, Waastu, Citra, "Pengantar ke Ilmu Budaya Bentuk Arsitektur Sendi-sendi Filsafatnya Beserta Contoh-
Contoh Praktis”, Gramedia Pustaka Utama, Jakarta, 1988. 
[2] L.L. Beranek, \& I.L. Ver, "Noise and Vibration Control Engineering", John Wiley \& Sons, New York, 1992.

[3] Rabi, $d k k$., "Perbaikan Kualitas Akustik Ruang Menggunakan Plafon Ventilasi Berdasarkan Waktu Dengung Studi Kasus Ruang Keluarga Pada Rumah Tipe 70", (digilib.its.ac.id/public/ITSpaper-24573-2410105013-paper.pdf).

[4] Suyatno, "Pengembangan Parameter Desain Akustik Ruang Pagelaran Gamelan Jawa", Disertasi, Institut Teknologi Bandung (ITB), Bandung, 2016.

[5] L.L. Doelle, L. Prasetio, "Akustik Lingkungan", Penerbit Er- langga, Jakarta, 1993.

[6] W. Ahnert, \& W. Schmidt, "Fundamentals to Perform Acoustical Measurements", Appendix to EASERA, 2006.

[7] F.A. Everest, K. Pohlmann, "Master Handbook of Acoustic", McGraw-Hill inc., New York, 2009.

[8] Suyatno, dkk., "Karakteristik Akustik ruang sidang jurusan Fisika FMIPA ITS sebagai ruang konferensi”, Jurnal Fisika dan Aplikasinya, vol. 13, no 1, hal. 23-26, 2017. 